\title{
Rehabilitation of Hemiplegia: Indices of Assessment and Prognosis
}

\author{
L. J. HURWITZ, G. F. ADAMS
}

British Medical fournal, 1972, 1, 94-98

\section{Size of the Problem}

The true incidence of cerebrovascular accidents in Britain is not known, because no representative morbidity statistics are kept. The information available is the result of guesswork based on studies of small sections of population.

In one from Great Britain ${ }^{76} 391$ patients were admitted to hospital with cerebrovascular accidents in 1963 from a population of 340,000 , an incidence of 1.2 per 1,000 per annum, but the comparable incidence for Middlesex County, Connecticut, ${ }^{77}$ was 2.3 per 1,000 per annum, giving an adjusted rate for the U.S.A of 1.7 per 1,000 . Statistics from a study in Baltimore ${ }^{78}$ projected to the whole country yielded an estimate of " 500,000 living stroke victims, almost $350,000(70 \%)$ of them aged 65 and over" in the United States, but the President's Commission ${ }^{79}$ estimated that there were at least two million people alive in that country in 1964 who had suffered a stroke. An estimate from the office of Population Censuses and Surveys ${ }^{80}$ states that there are 130,000 people in Great Britain who have significant impairment from stroke.

Probably the incidence in both the United Kingdom and United States may be just less than 2 per 1,000 population per annum, and it rises sharply with advancing age especially amongst women. Similar findings have been reported from Denmark. ${ }^{81}$ A family doctor, ${ }^{82}$ extrapolating his experience in a practice of 2,500 arrived at the same incidence. He found that about five new hemiplegics appear in the practice each year bringing 15-20 hemiplegics of all varieties under his notice annually. Of these he expects $60 \%$ "maxi" strokes, 20\% "mini" strokes, and 20\% miscellaneous cerebrovascular disorders.

Applying these figures to a population of 250,000 (the basis for a district hospital) suggests an incidence of 500 strokes per annum, of which 250 will need a lot of help and about 150 will be added to the accumulated number needing continued care each year.

\section{Recovery From Stroke}

We tend to think of recovery from strokes in three phases: two weeks concerned with survival; eight to twelve weeks of effort to restore activity and independence in walking, standing, and self-care; and two years-the time that may elapse before the full capacity of the patient to participate in normal social activities may be realized. Management at the onset of a major stroke is described elsewhere in this symposium and was also discussed recently. ${ }^{83}$ Here we are concerned with recovery in the two later stages.

Elsewhere a description ${ }^{84}$ has been given of the clinical criteria used to assess capacity and define the barriers which may delay recovery and require special consideration in treatment. ${ }^{85-90}$ Special aspects of assessment and treatment have also been described in two comprehensive symposia. ${ }^{91-92}$ Two points of rehabilitation which need special emphasis are that initial assessment should be directed towards accepting patients for treatment and not to their rejection, and that the process of

Queen's University and Wakehurst House, Gity Hospital, Belfast L. J. HURWITZ, M.D., F.R.C.P.ED., Late Consultant Neurologist, Royal Victoria and Claremont Street Hospitals. (We regret that Dr. Hurwitz died shortly after this article had been prepared; see B.M.F., 1971, 4, 306) G. F. ADAMS, M.D., F.R.C.P., Professor of Geriatric Medicine

recovery is spontaneous and slow. Nerve cells which die do not recover, nor will their connexions remyelinate. Improvement in function occurs partly because damaged tissue regains vitality, and partly because other functions served by healthy brain provide intellectual tricks necessary to compensate for some of what has been lost.

Recovery by these mechanisms may account for the improvement observed in the first six months after a stroke, but improvement may be even more protracted suggesting that there are other adaptive processes. Thus Blakemore and Falconer ${ }^{93}$ have shown that patients after temporal lobectomy may not recover learning ability until three to five years after operation. It is the sad misfortune of most patients who have strokes to be the victims of a combination of old age and continuing disease.

\section{INFLUENCE OF SPECIFIC HANDICAPS}

\section{Mental Barriers}

Speech.-It must be more than enough to endure and contend with the physical disabilities of hemiplegia without the added handicap of aphasia, and no one would deny these patients any means of encouragement that would help to maintain morale and improve their prospects. Their frustrations ${ }^{94}$ include being regarded as brainless, being subjected to the indignity of having things done for them which they could well do for themselves, and, what is worse, not doing for them those things they cannot possibly be expected to do.

Most patients with severe expressive aphasia but intact comprehension will be much less handicapped in achieving independence than those with poor comprehension. Nevertheless, the fact that people with poor comprehension do badly so often may be partly because they, and those responsible for them, are given no instruction or opportunity in alternative means of communication such as mime, which may bypass the use of words. Society, both medical and lay, is very "wordorientated."

Not all aphasiacs will respond to speech therapy, and the problem in treatment is to decide how best to use the services of trained speech therapists.

It is uncertain whether even their best efforts achieve more than vis medicatrix naturae. Butfield and Zangwill ${ }^{95}$ suggested that they do, claiming improvement in some of the 14 patients who had speech therapy six months or more after the onset of the disorder "when relatively little further spontaneous improvement was to be expected." Sommerville $e^{96}$ and Paterson ${ }^{97}$ concur with this view. Marks et al.,98 though finding results poor in $49.7 \%$, thought that expressive aphasia was the most likely to be helped. Others, ${ }^{99-101}$ however, have noted that results reported after speech therapy were no better than those obtained by spontaneous recovery alone. Their opinion supports the view that recovery of language is physiological: spontaneous rather than re-learned. ${ }^{102}$

Our own experience highlights the need for painstaking followup. Of 133 patients referred in a four-year period, 12 were thought to have been improved by speech therapy. Many others, considered at speech assessment to have a good prognosis, improved without treatment. Some were unable to respond because of dementia.

We have no doubt that speech therapists have an essential part to play in the management of some aphasic patients. We look upon their function as most helpful in finding out which aspect of language is most involved, and in advising which methods of communication may best be developed to offset what has been lost. However, no one seems to have been able, yet, to define criteria of 
assessment to distinguish those who will benefit from those who will not, though aphasia from left cerebral hemisphere lesions in sinistrals is likely to be less persistent than in dextrals, ${ }^{103}$ and aphasia occurring from right hemisphere lesions is seldom pronounced and enduring even in left-handed patients. ${ }^{104}$

Requirements for the treatment of aphasic patients defined by Miss Kay (Royal Victoria Hospital, Belfast), ${ }^{105}$ were: (1) Visual contact with people and with objects. (2) Sound location-evident when the patient turns his head in response to sound. (3) Handeye co-ordination-that is, willingness to reach for objects. (4) Ability to imitate the mouthing of words. (5) Response to simple mime. (6) Response to repetitive speech to indicate: (a) if the palate is working, (b) the extent of articulation possible, (c) whether the normal voice is available, (d) whether language is complicated by jargon. (7) Penmanship and ability to sign name. (8) A capacity to respond to pictures and written words.

In addition to the therapist's regular sessions there should be instruction of relatives and other people who come in contact with the patient. Sometimes the needs of the patient may be met by auxiliary help guided by a trained therapist, and even without formal speech therapy much can be done by unskilled people ${ }^{106}$ willing to give time and consideration to the development of an appropriate communications system with a responsive patient.

Despite severe aphasia some patients have produced important artistic work, ${ }^{107-8}$ and others have returned to responsible jobs, ${ }^{109}$ small but significant minorities. When there is language difficulty, pantomime, gesture, art, design, or music should be introduced into the patient's life to increase the opportunities for learning and recreation. Every now and again the patient will communicate in an unexpected way. One, who had a right hemiplegia, subsequently wrote quite fluently, and with good penmanship, using her left hand, but the script appeared as mirror-writing. Efforts to establish forward writing were stopped because these were not successful and distressed her. Another patient, with jargon aphasia, remained a great trial to his wife until sign and pictorial language was adopted and he could be persuaded to keep silent.

Perhaps the most we can say in the light of present knowledge is that some aphasiacs will retain or recover capacity to assimilate instruction in daily living and occupational pursuits; some will do no more than "keep going" with diversional activities; others may respond slowly but continuously over many months to speech therapy; and still others, though remaining aphasic, will appreciate and need only the moral support of occupational therapy and a communication system unique to themselves.

Dementia.-Of all mental barriers to the recovery of hemiplegic patients undoubtedly dementia ${ }^{110}$ is the greatest. This diagnosis implies diffuse neuronal loss and may be difficult to distinguish from the behavioural effects of more local lesions (especially when there are language difficulties). A questionnaire giving a "dementia score" is helpful"11 and simple performance tests using educational toys"o help to assess reasoning and critical intellectual powers. Unfortunately, the questionnaire is unhelpful in aphasic patients, as are manual tasks in patients with constructional apraxia. No single test is a wholly reliable indicator of dementia when poorly performed, and sometimes a better indication is obtained from a sense of willingness and an alert glint in the patient's eye combined with the opinion amongst nurses and relatives that the patient is "with it".

Memory Disturbance.-Sometimes there is profound memory disturbance without other evidence of dementia. This probably occurs in relation to lesions of the hippocampus. ${ }^{112}$ The pattern of memory loss may involve recall, leaving registration intact. Sometimes there is disruption of the chronological order of memory. Confabulation is seldom appreciable, but occasionally a confabulatory answer may have other origins. ${ }^{113}$ A few patients overcome the handicap to learning by the use of detailed written instructions.

Motivation.-It has been said that an important factor in the rehabilitation of the hemiplegic patient is motivation, ${ }^{114}$ but this means different things to different people. The term may be used mistakenly to imply that the patient "is not making an effort" when the apparent lack of effort is due to a genuine lack of capacity or is the result of a sense of hopelessness.

True. Depression.- This may appear at the onset of a stroke, complicating clouded consciousness, or later even at a time when good progress is being made, bringing the risk of suicide.

Four behavioural changes associated with cerebrovascular disease and strokes may be confused with poor motivation and depression.

Three of these are well known-the facile switching from expressions of joy to sadness known as emotional lability, a general loss of confidence, and a firm decision to give up the struggle- to do no more. The fourth, claimed by Fisher ${ }^{115}$ to be characteristic of cerebrovascular disease, is emotional incontinence, a condition quite different from lability, which may be a major bar to rehabilitation. Outbursts of weeping (less commonly of laughter), clearly unrelated to the underlying affect, are provoked by the slightest stimulus. It must be emphasized that some of these patients are intellectually well preserved and do not have obvious features of pseudobulbar palsy. The symptom is nearly always refractory to treatment and the best that can be done is to protect the patient from attempts to treat it as depression.

\section{MOTOR FUNCTION}

There are no positive ways of restoring function in hemiplegic paralysis and, at best, rehabilitation is limited to the means which will enable the most to be made of spontaneous recovery. Nevertheless, despite this, optimism, encouragement, and constant reassurance over many discouraging months are most important ingredients of the treatment of patients with strokes. The object must be to help the patient to help himself; "the patient will shoot the goals and you are there to help him. In bygone days people rivalled each other in trying to kick the patient through the goals."116 Passive movements, heat, splints, slings, and stimulation of sensory input help to limit contracture, especially at the shoulder in a hemiplegic arm, and to encourage the use of any return of voluntary power. Ipsilateral hemisphere control over hand function after strokes is less well acquired than for the proximal parts of the limb.

There is usually more hope of recovery of function in the leg, especially when the patient can lift the extended limb from the bed in 2-3 weeks, and dorsiflex the foot within 4-6 weeks, of the onset. Ability to stand and walk are more primitive acquisitions than precision use of hand and arm, and attempts can be made from early weeks to stimulate a positive supporting response in the hemiplegic leg by standing, balance exercises, and walking. Understanding of the complex mechanisms involved in control of posture and movement has been advanced greatly in recent years by Martin and others, ${ }^{117-8}$ and modern treatment of hemiplegia has benefited by application of the principles involved by Bobath ${ }^{11}$ in new techniques of physiotherapy.

The essentials include: (1) Emphasis in treatment on normal postural settings and patterns of movement rather than muscle strengthening. (2) Emphasis on sensory input and awareness of activity in the hemiplegic limbs. (3) Concentration on restoring antigravity mechanisms, control of weight-bearing and regaining normal equilibrium reactions on the hemiplegic side. (4) Restriction of over-activity in the sound limbs lest they are used excessively at the expense of the affected side. (5) Initiation of movements from the proximal muscle groups (shoulder girdle and hip).

Restoration of independence in walking, self-care, and social reliability may involve the patient, the therapists, and the relativesas well as doctors and nurses-in months of painstaking work, but the reward is to see a confused, incontinent, densely disabled patient restored to steady, rhythmical movements and a normal walk instead of being left with an unstable, awkward hemiplegic hobble.

In some patients, despite the physiotherapist's best efforts, marked postural abnormalities persist with misalignment of body segments. The head becomes flexed forward and laterally, and there is flexion of the body on the pelvis with rotation of the spine. Hypertension and bilateral pyramidal signs in these patients imply deeply extending infarcts and lacunae, ${ }^{115}$ and mobility (even in a self-propelling chair) is seldom regained. In other instances there are specific problems of gait. ${ }^{120}$ In striking contrast to Parkinsonism, where steppage is preserved, some patients after stroke have neither stepping nor equilibrium, can neither stand nor walk, and appear 
to have no idea of any of the components of walking. They may attempt to progress sideways, or to advance one foot while the other retreats and the body falls backwards. Such back-sliding is often accompanied by clutching at objects and people nearby. Patients with these handicaps respond badly to efforts at reeducation.

Apraxia.-Apraxia is inability to perform a previously established pattern of movement though muscle strength, sensation, and co-ordination appear to be unimpaired. It is mentioned frequently as a complication of strokes, involving facial movements of aphasic patients, the precision use of the fingers combined with neglect of the hand, or perhaps it is a component of the disorganized patterns of walking described earlier.

Left-sided apraxia is probably quite common in patients with right hemiplegia (sympathetic apraxia' ${ }^{121}$ ), but often it is transient and disappears in a few weeks. Response to verbal command is poor or absent in such patients but usually objects are manipulated normally. Comprehension defect can be excluded by the ability of the patient to make correct verbal responses about the movement. The link between apraxia and verbal command ${ }^{122}$ makes it desirable to measure apraxia and object agnosia (which must be extremely uncommon) with a description of the test used in their demonstration.

Dependencies and Appliances.-In the millenia since Oedipus solved the riddle of the Sphinx ${ }^{123}$ appliances other than the old man's staff have been made available to the hemiplegic patient. A quadriped in preference to a tripod is essential to some patients in the early stages, and to others for the rest of their days. Even so, we have recently had to write to the British Standards Institute on behalf of such patients to advise against a proposed regulation which would deprive them of adjustableheight walking aids. Grant, ${ }^{124}$ and Droller and Thornely, ${ }^{125}$ have discussed practical aspects giving detailed attention to the mechanics of rehabilitation, especially the appliances, to domestic reconstruction and adaptations, and to the personal reorientation necessary to ensure maximum independence and social reliability.

The essentials are: (1) Personal independence in feeding, toilet, washing, dressing. (2) Domestic independence in cooking, washing up, cleaning, sewing, laundry. (3) Home Care.-Access room to room, stairs, passage-ways, bedroom, toilet, bathroom, kitchen. (4) Appliances.-Toe-spring, corset or brace, caliper. (5) Mobility, indoor and outdoor, added if need be by walking aid, chair, ramps, garage redesign.

As we have referred to garages it may be as well to add a note on driving. Unfortunately few of the patients who have suffered a major stroke should be allowed to drive a motor-car again. Hemianopia, intellectual loss (especially lack of insight), the feebleness of old age, and liability to fits and faints, variously combined with weakness and clumsiness, preclude this activity. Very occasionally it may be possible, but we suggest as criteria that driving after strokes should be encouraged in patients only: (a) who have had no further episodes of neural dysfunction for a year; (b) whose vision, intellect, co-ordination, and general health have been stringently assessed; (c) after passing a test for handicapped drivers using a suitably adapted car.

\section{SENSORY DEFICIT}

The influence of sensory input on motor function of the brain is well known, but there is little precise information about the effect of sensory deprivation on recovery of function after hemiplegia. Buskirk and Webster ${ }^{126}$ investigated the rate of recovery of cortical and subcortical sensory modalities in 35 hemiplegic patients and the prognosis of those in whom sensory deficits persisted. Two-point discrimination returned to normal in half of their patients in about six weeks, whereas only a quarter of those with impaired pain or vibratory sense improved, and recovery was longer delayed (2-4 months). Twopoint discrimination was never impaired alone, always in combination with one or both of the other modalities, and prognosis for rehabilitation was worse if the deficit in two-point discrimination persisted.

Persistent flaccidity, especially of the leg, which has been correlated with sensory loss and related to lesions of the parietal cortex, is another adverse factor because of the handicap it imposes on recovery of a confident walk. Muscular atrophy determined by lesions of the parietal cortex is rare but may have a bearing on this. The extent of discriminative sensory loss, and therefore prognosis for rehabilitation, may depend on the size of the lesion both in depth (from cortex into subcortical layers), and in anteroposterior or lateral area. Nevertheless, ability to walk is always seriously impaired when a loss of joint-position sense persists.

Anosognosia.-This is found almost exclusively in right hemisphere lesions in association with sensory deficit. Explicit denial of the hemiplegia, and delusionary descriptions of the left limbs always carry a poor prognosis for recovery of independence. Over many months, and particularly if the delusions are not reinforced by the staff, some improvement in the anosognosia usually occurs. The electroencephalograph is invariably abnormal when there is anosognosia and there is parallel improvement in the record as the anosognosia declines. The electroencephalograph is otherwise not helpful in assessing prognosis, because it may or may not be abnormal when there is dementia.

\section{Prognosis}

Regular assessment of mental and physical capacity in hemiplegia is obviously necessary as a basis of an appropriate programme of treatment, and to guide all those who are responsible for the patient's care, , $27-8$ but it is also required to give at least an approximate indication of prospects of recovery (Fig ${ }^{129}$ ).

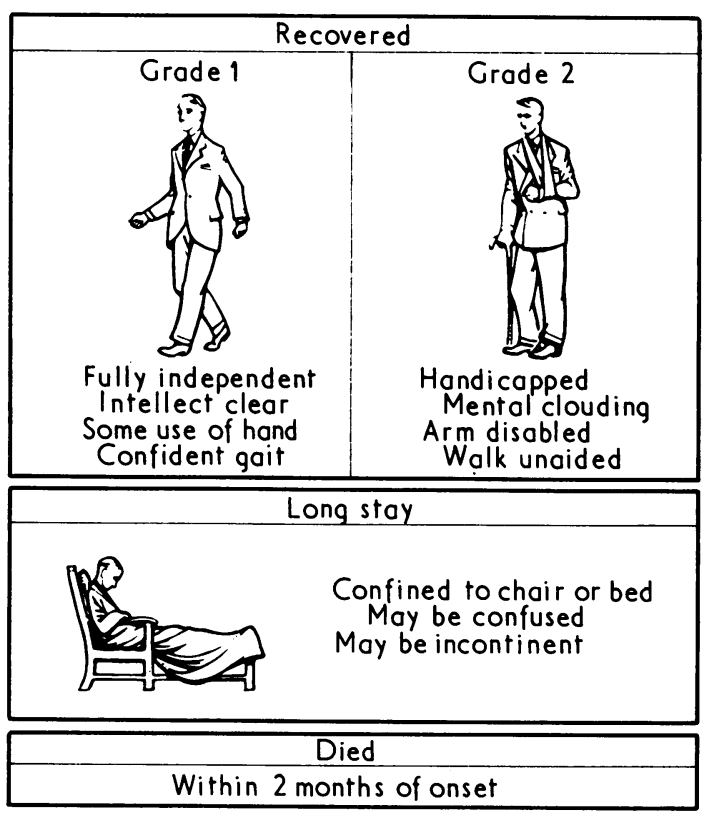

FIG. 1-Destiny of Survivors of Stroke

We have found that about $10 \%$ of patients referred for rehabilitation fail to survive the first two months of the stroke, and $30 \%$ require continued care as chairfast invalids. Nevertheless $60 \%$ will recover, and more than one-third of these will be fully independent, intellectually clear, with some effective use of their disabled hand and a confident gait (Fig. 120). The remainder of the "recovered" patients will be more handicapped, perhaps by a mental barrier, or by sensory deficit or poor return of voluntary power, and probably by the need for continued use of caliper, tripod, and other appliances. 


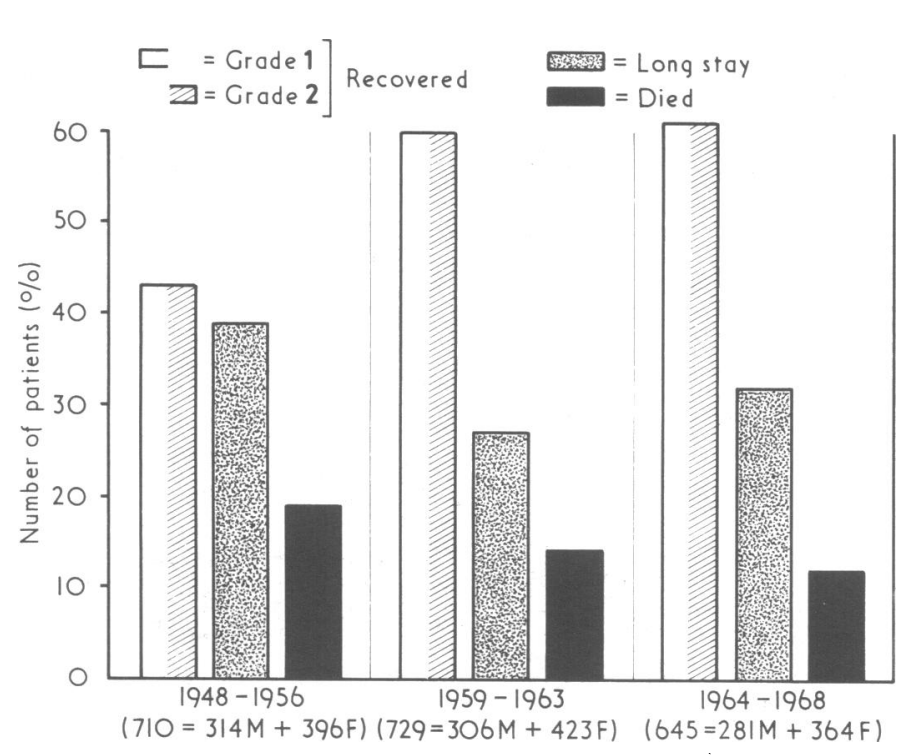

FIG. 2-Improvement in Prognosis of Stroke since 1948. An Analysis of 2,084 Patients.

The grade of recovery to be expected may be evident as early as 4-6 weeks in patients who are making good progress, but it is seldom possible before 10 or 12 weeks to distinguish with confidence potential recoveries from those who will need continued care. When in doubt a decision to lessen intensive efforts to restore activity should be deferred at least until 16 weeks. Even at this stage occasional patients unexpectedly discover hidden intellectual and rhysical reserves, showing improvement as late as six or eight months after onset, and then progressing slowly until, a year or 18 months later, they are fully independent and living a relatively normal life. Unfortunately this rewarding phenomenon is rare except when the hemiplegia is attributable to lesions other than those caused by hypertension or diffuse arterial diseases.

There is evidence that the right cerebral hemisphere leads for constructional tasks in people who have left hemisphere dominance for language. It is our experience that patients with left hemiplegia more often show constructional apraxia and visuospatial difficulties. Though individual patients with left hemiplegia can do well, taken as a group they do less well than right hemiplegics including those with aphasia.

The more useful prognostic signs are summarized in Table I.

TABLE I-Prognosis of Recovery

\begin{tabular}{|c|c|c|c|c|}
\hline \multicolumn{3}{|c|}{ Prognostic signs } & Encouraging & Discouraging \\
\hline $\begin{array}{l}\text { Recovery from cor } \\
\text { Incontinence } \\
\text { Depression } \\
\text { Dementia ... } \\
\text { Recent memory } \\
\text { Demeanour } \\
\text { Language... } \\
\text { Positive supportin } \\
\text { Balance .. } \\
\text { Posture .. } \\
\text { Walk } \\
\text { Proprioception } \\
\text { Anosognosia } \\
\text { Apraxia ... }\end{array}$ & 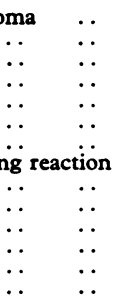 & $\begin{array}{l}\cdots \\
\because \\
\because \\
\therefore \\
\therefore \\
\therefore \\
\therefore \\
\therefore \\
\therefore \\
\therefore\end{array}$ & $\begin{array}{c}\text { Rapid } \\
\text { Clears in 2-3 weeks } \\
- \\
\text { Good } \\
\text { Energetic } \\
\text { Normal } \\
\text { Early recovery } \\
\text { Early recovery } \\
\text { Well-aligned } \\
\text { Rhythmical } \\
\text { Unaffected } \\
- \\
\text { Transient }\end{array}$ & $\begin{array}{c}\text { Slow } \\
\text { Recovery delayed } \\
+ \\
+ \\
\text { Bad } \\
\text { Apathetic } \\
\text { Receptive aphasia } \\
\text { Delayed } \\
\text { Delayed } \\
\text { Eccentric } \\
\text { Disorganised } \\
\text { Severe loss } \\
+ \\
\text { Persistent }\end{array}$ \\
\hline
\end{tabular}

\section{The Long Way Back to Independence}

In Table II we have set out a scheme of after-care in effective use in the Belfast region despite its imperfections. To some this may seem to be an unobtainable ideal, to others the irreducible minimum. A medical social worker has observed that, like other infirmities which predominantly involve old people, "stroke is a family illness." 130 Intelligent use of the services available to be
TABLE II-Contemporary Model for Rehabilitation After Major Stroke

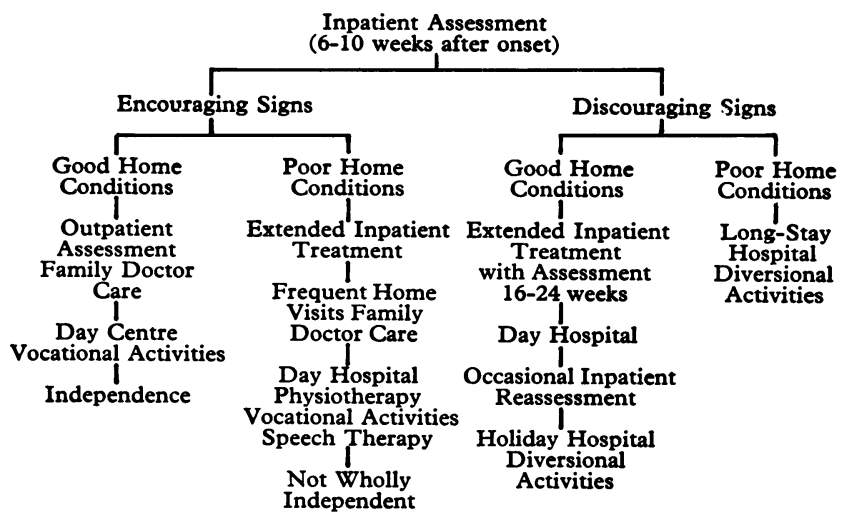

used on behalf of the hemiplegic calls for effective medical social work before discharge, so that the patient returns to a secure home and to relatives, friends, or voluntary workers confident in the care they offer because they have been properly informed. Then they may know what they can or cannot expect of the patient and what the patient has a right to expect of them.

In the months, or years, of follow-up after discharge, some patients attend local authority day centres for a few hours once or twice during the week. Others require continued treatment in day hospital, distinguished from a day centre by its link with other hospital outpatient services and having medical and nursing supervision and treatment available for five days a week. Doctors, nurses, therapists, social service workers, and other necessary staff may be difficult to recruit, but their work and influence can cover a wide area, especially when supported by such established hospital departments as geriatric medicine, neurology, rheumatology, and physical medicine, closely allied to family medicine. Transport often proves to be the main limiting factor. In this and other respects there are opportunities for voluntary action to be mobilized on behalf of the hemiplegic members of society.

In conclusion we wish to stress that it is never easy to ascertain precisely the nature of hemiplegic disability, and those who come in contact with the patient do well to avoid remarks which might imply that he cannot or will not do something. Rather one should say "the patient does not do what is asked." "Does not" will cover everything from "will not" to "cannot," from "lack of motivation" to "apraxia."19

Earlier we referred to hemiplegics who find themselves unable to make the effort necessary to be up and doing again, and where there is profound disability at great age we must respect the desire for peace and quiet expressed by T. S. Eliot.

I no longer strive to strive towards such things

(Why should the aged eagle stretch its wings ?).

\section{References}

1 Hicks, S. P., and Warren, S., Archives of Pathology, 1951, 52, 403.

2 Todd, R. B., Medico-Chirurgical Transactions, 2nd series, 1844, 9, 301.

3 Gull, W., Guy's Hospital Reports, Series 3, 1855, $1,12$.

- Hunt, J. R., American fournal of Medical Science, 1914, 147, 704

5 Hultquist, G. T. J., Uber Thrombose und Emboli der Arteria Carotis. Stockholm, Norstedt, 1942 .

- Fisher, C. M., Archives of Neurology and Psychiatry, 1954, 72, 187.

7 Hutchinson, E. C., and Yates, P. O., Lancet, 1957, 1, 2.

8 McGee, D. A., McPhedran, R. S., and Hoffman, H. J., Neurology, 1962, 12,848 .

- Martin, M. J., Whisnant, J. P., and Sayre, G. P., Archives of Neurology, $1960,3,530$.

${ }^{10}$ Baker, A. B., Dahl, E., and Sandler, B., Neurology, 1963, 13, 445.

11 Fisher, C. M., Gore, I., Okabe, N., and White, P. D., fournal of Neuropathology and Experimental Neurology, 1965, 24, 455.

12 Kendell, R. E., and Marshall, J., British Medical fournal, 1963, 2, 344

13 Gunning, A. J., Pickering, G. W., Robb-Smith, A. H. T., and Russell, R. W. R., Quarterly Fournal of Medicine, 1964, 33, 133.

14 Brice, J. G., Dowsett, D. J., and Lowe, R. D., British Medical fournal, $1964,2,1363$.

15 Millikan, C. H., Circulation, 1965, 32, 438.

16 Schwartz, C. J., and Mitchell, J. R. A., British Medical fournal, 1961, 2, 1057.

${ }^{17}$ Bhattacharii, S. K., Hutchinson, E. C., and McCall, A. J., British Medical fournal, 1967, 3, 270. 
18 Fisher, C. M., Neurology, 1959, 9, 333.

19 Russell, R. W. R., Lancet, 1961, 2, 1422.

20 Ashby, M., Oakley, N., Lorentz, I., and Scott, D., British Medical Fournal, 1963, 2, 894.

21 McBrien, D. J., Bradley, R. D., and Ashton, N., Lancet, 1963, 1, 697.

${ }^{22}$ Denny-Brown, D., A.M.A. Archives of Neurology, 1960, 2, 194

23 Gunning, A. J., Pickering, G. W., Robb-Smith, A. H. T., and Russell, R. W. R., Quarterly fournal of Medicine, 33, 155 .

24 David, N. J., Klintworth, G. K., Friedberg, S. J., and Dillon, M., Neurology, 1963, 13, 708.

${ }^{25}$ Bladin, P. F., Radiology, 1964, 82, 615

26 Dalal, P. N., Shah, P. M., Sheth, S. C., and Deshpande, C. K., Lancet, $1965,1,61$.

27 Fisher, C. M., and Adams, R. D., Fournal of Neoropathology and Experimental Neurology. 1951, 10, 92.

28 Blackwood, W., Hallpike, J. G., Kocen, R. S., and Mair, W. G. P., Brain, 1969, 92, 897.

29 Castaigne, P., Lhermitte, F., Gautier, J. C., Escourolle, R., and Derouesne, C., Brain, 1970, 93, 231.

${ }^{30}$ Metz, H., Murray-Leslie, R. M., Bannister, R. G., Bull, J. W. D., and Marshall, J., Lancet, 1961, 1, 424.

31 Sarkari, N. B. S., Holmes, J. M., and Bickerstaff, E. R., Fournal of Neurology, Neurosurgery, and Psychiatry, 1970, 33, 194.

32 Marshall, J., and Shaw, D. A., British Medical fournal, 1959, 1, 1614.

ss Howard, F. A., et al., Fournal of the American Medical Association, 1963, 183, 921 .

34 Carter, A. B., Cerebral Infarction. Oxford, Pergamon, 1964.

${ }^{35}$ Acheson, J., Quarterly fournal of Medicine, 1971, 40, 15.

s6 Merrett, J. D., and Adams, G. F., British Medical fournal, 1966, 2, 802.

Robinson, R. W., Demirel, M., and LeBeau, R. J., Fournal of Chronic Diseases, 1968-9, 21, 221.

38 Globus, J. H., and Epstein, J. A., fournal of Neuropathology, and Experimental Neurology, 1953, 12, 107.

so Bruetman, M. E., Fields, W. S., Crawford, E. S., and De Bakey, M. E., Archives of Neurology, 1963, 9, 458.

Archives of Neurology, 10 Russell, D. S., Proceedings of the Royal Society of Medicine, 1954, 47, 689.
.

1 Okinaka, S., and Kameyama, M., Transactions of the American Neurological Association, 1960, 85, 114.

12 Charcot, J. M., and Bouchard, C., Archives de Physiologie Normale et Pathologique, 1868, 1, 110.

43 Green, F. H. K., Fournal of Pathology and Bacteriology, 1930, 33, 71.

4 Matsuoka, S., Proceedings of the 1 st International Congress of Neuropathology (Rome). Turin, Rosenberg and Sellier, 1952.

45 pathology (Rome). Turin, Rosenberg and

t6 Cole, F. M., and Yates, P. O., Neurology, 1968, 18, 255.

47 Cole, F. M. M., and Yates, P. O., Neurology, 1968

48 Marks, J. S., Neurology, 1960, 10, 278.

49 McKissock, W., Richardson, A., and Walsh, L., Lancet, 1959 2, 683.

so McKissock, W., Richardson, A., and Walsh, L., Brain, 1960, 83, 1

51 Marshall, J., and Kaesar, A. C. British Medical fournal, 1961, 2, 73.

52 Carter, A. B., Lancet, 1970, 1, 485.

53 Bickerstaff, E. F., British Medical fournal, 1964, 2, 82.

54 Levine, J., and Swanson, P. D., Annals of Internal Medicine, 1969, 70, 807.

${ }_{55}^{55}$ Silverstein, A., Neurology, 1961, 11, 310.

${ }^{56}$ Adeloye, A., Seriki, O., Luzzato, L., and Essien, E. M., fournal of Neurology, Neurosurgery and Psychiatry, 1969, 32, 470.

57 Goldstein, E., and Porter, D. Y., Archives of Neurology, 1969, 20, 533. Millikan, C. H., Siekert, R. G., and Whisnant, J. P., Circulation, 1960, 22, 1002 .

${ }^{59}$ McKissock, W., Richardson, A., and Taylor, J., Lancet, 1961, 2, 221.

6 Ford, R., and Ambrose, J., Brain, 1963, 86, 189.

61 Achar, V. S., Coe, R. P. K., and Marshall, J., Lancet, 1966, 1, 161.

62 Wells, C. E., Neurology, 1961, 11, no. 4, Part 2, 112.

${ }^{63}$ Rhoton, A. L., Klinkerfuss, G. H., Lilly, D. R., and Ter-Pogossian, Rhoton, A. L., Klinkerfuss, G. H., Lilly, D. R., and Ter-Pogossian,
M. M., Archives of Neurology, 1966, 14, 506.
Marshall, J., and Popham, M. G., fournal of Neurology, Neurosurgery, and Psychiatry, 1970, 33, 201.

${ }^{65}$ du Boulay, G., in Modern Trends in Neurology, ed. D. Williams, 4th edn, chapter 13. London, Butterworths, 1967.

os Marshall, J., The Management of Cerebrovascular Diseases, 2nd edn. London, Churchill, 1968.

67 Carter, A. B., British Medical fournal, 1961, 2, 70.

68 Toole, J. F., Lancet, 1964, 1, 872.

69 Sheehan, S., Bauer, R. B., and Meyer, J. S., Neurology, 1960, 10, 968.

70 Fields, W. S., et al., Fournal of the American Medical Association, 1970 , 211, 1993.

${ }^{71}$ Liversedge, L. A., and Smith, V. H., Brain, 1961, 84, 274.

72 Mawdsley, C., Samuel, E., Sumerling, M. D., and Young, G. B., British Medical fournal, 1968, 3, 521 .

73 Wood, E. H., and Hilal, S. K., in Extracranial Cerebrovascular Disease and its Management, ed. J. A. Gillespie, chapter 4. London, Butterworths, 1969.
74 Chamberlain, M. J., Hospital Medicine, 1967-8, 2, 1252.

75 Rifkind, B. M., British fournal of Hospital Medicine, 1970, 4, 683.

76 Acheson, R. M., and Fairbairn, A. S., British Medical fournal, 1970, 2,621 .

${ }^{77}$ Eisenberg, H., Morrison, J. T., Sullivan, P., and Foote, F. M., Fournal of the American Medical Association, 1964, 189, 883.

78 Stamler, J., in Proceedings of the National Stroke Congress, 1964, ed. R. E. de Forest, p. 24. Illinois, Springfield Thomas, 1966.

79 The President's Commission of Heart Disease, Cancer and Stroke. Washington, U.S. Government, 1964.

80 Harris, A. I., Cox, E., Smith, C. R. W., Handicapped and Impaired in Great Britain, part I. London, H.M.S.O., 1971.

81 Marquardsen, J., Acta Neurologica Scandinavica, 1969, 45, Suppl. 38.

${ }^{82}$ Fry, J., Personal communication, 1971.

${ }_{83}$ Hurwitz, L. J., British Medical fournal, 1969, 3, 699.

84 Adams, G. F., British Medical fournal, 1971, 1, 91.

85 Adams, G. F., and Hurwitz, L. J., Lancet, 1963, 2, 533.

86 Critchley, M., British Medical fournal, 1955, 2, 284.

87 Allison, R. S., The Senile Brain. London, Arnold, 1962.

88 Isaacs, B., Gerontologia Clinica, 1963, 5, 8.

89 Isaacs, B., Gerontologia Clinica, 1967, 9, 295.

90 Isaacs, B., Modern Geriatrics, 1971, 1, 390.

92 Modern Geriatrics, 1971, 1, 368.

93 Blakemore, C. B., and Falconer, M. A., fournal of Neurology, Neurosurgery, and Psychiatry, 1967, 30, 364

94 Mead, S., Lancet, 1963, 2, 574.

os Butfield, E., and Zangwill, O. L., Fournal of Neurology, Neurosurgery, and Psychiatry, 1946, 9, 75.

Sommerville, J. G., Proceedings of the Royal Society of Medicine, 1970, $63,1146$.

97 Paterson, A., Modern Geriatrics, 1971, 1, 403.

98 Marks, M., Taylor, M., and Rusk, H. A., Neurology, 1957, 7, 837.

Godfrey, C. M., and Douglass, E., Canadian Medical Association fournal,

100 Sarno, M. T., Silverman, M., and Sands, E., Fournal of Speech and Hearing Research, 1970, 13, 607.

101 Sarno, M. T., Silverman, M., and Levita, E., Fournal of the American Geriatrics Society, 1970, 18, 405

102 Lenneberg, E. H., Biological Foundations of Language. New York, Wiley, 1967.

103 Subirana, A., Brain, 1958, 81, 415.

104 Zangwill, O. L., in Disorders of Communication, ed. L. Rioch and E. A. Weinstein. Baltimore, Williams and Wilkins, 1964.

105 Kay, B., Personal communication, 1971.

106 Griffith, V. E., A Stroke in the Family, Penguin Books, 1970.

107 Luria, A. R., Tsvekova, L. S., and Futer, D. S., fournal of the Neurological Sciences, 1965, 2, 288.

108 Critchley, M., Aphasiology, London, Arnold, 1970.

109 Ritchie, D. E., Stroke: a Study of Recovery, New York, Doubleday, 1961.

110 Carroll, D., Fournal of Chronic Diseases, 1962, 15, 179.

111 Blessed, G., and Tomlinson, B. E., in Psychiatric Disorders in the Aged. World Psychiatric Association Symposium, p. 310, Geigy, 1965

112 Scoville, W. B., and Milner, B., fournal of Neurology, Neurosurgery, and Psychiatry, 1957, 20, 11 .

Psychiatry, 1957, 20, 11.
113 Geschwind, N., Brain, 1965, 88, 585.

114 Lee, P., in Cerebral Vascular Diseases, ed. I. S. Wright and C. H. Millikan, p. 171 . New York, Grune and Stratton, 1958.

115 Fisher, C. M., in Cerebral Vascular Disease, ed. J. F. Toole, R. G. Siekert, and J. P. Whisnant, p. 232. New York, Grune and Stratton, 1968.

116 Grant, W. R., Modern Geriatrics, 1971, 1, 6.

117 Martin, J. P., The basal Ganglia and Posture, London, Pitman Medical, 1967.

118 Hurwitz, L. J., Practitioner, 1970, 204, 188.

119 Bobath, B., Physiotherapy, 1959, 45, 279.

120 Critchley, M., Lancet, 1931, 1, 1221.

1 Geschwind, N., Transactions of the American Neurological Association, $1963,88,219$.

122 Ettlinger, G., Cortex, 1969, 5, 285.

123 The Encyclopaedia Britannica, 1964. London, Wm. Benton, 1964.

124 Grant, W. R., Principles of Rehabilitation. London and Edinburgh, E. \& S. Livingstone, 1963.

125 Droller, H., and Thornely, G., British Fournal of Physical Medicine, 1956, 19, 135.

126 Buskirk, C. V., and Webster, D., Neurology, 1955, 5, 407.

127 Millard, J. B., Annals of Physical Medicine, 1966, 8, 244.

128 MacLeod, R. D. M., and Williamson, J., Scottish Medical fournal, 1967, 12,384 .

${ }^{129}$ Adams, G. F., Gerontologia Clinica, 1971, 13, 181.

130 Antram, A., Modern Geriatrics, 1971, 1, 6. 